\title{
Ulakbim'de Dizinlenen Eğitim Bilimleri Dergilerinde 2017 Yılında Yayımlanan Makalelerin Çözümlenmesi ${ }^{1}$
}

\begin{tabular}{lccc}
\hline MAKALE TÜRÜ & Başvuru Tarihi & Kabul Tarihi & Yayın Tarihi \\
Araştırma Makalesi & 16.05 .2018 & 02.05 .2019 & 03.05 .2019 \\
\hline
\end{tabular}

Betül Özaydın Özkara (iD ${ }^{2}$

Isparta Uygulamalı Bilimler Üniversitesi

Öz

Bu çalıșma Ulakbim TR dizinde sosyal ve beșeri bilimler veri tabanı dergi listesinde eğitim bilimleri alanında dizinlenen 14 dergide 2017 yılında yayımlanan makalelerin incelenmesini amaçlamaktadır. Eğitim bilimleri alanındaki mevcut durumu belirlemek amacıyla önceki formlar incelenmiş ve araştırmacı tarafindan bu formlar üzerinden çalıșlarak geliștirilen yeni veri toplama formu kullanılmıștır. Toplam 830 makale bu form ile elde edilen verilerle incelenmiștir. Araştırmalarda, makalenin adı, yayımlandığı derginin adı, yayına kabul süresi, yazar sayısı, makale konusu, makale yöntemi ve deseni, örneklem düzeyi, verì toplama araçları, veri analizi yöntemi, örneklem sayısı, örneklem tekniŏi ve makalenin dili analiz edilmiștir. Analiz sonucunda; makalelerin en çok iki yazarlı olduğu, yayına kabul süresinin 1-6 ay arasında yoğunluk gösterdiği belirlenmiștir. Eğitimde ölçme ve değerlendirme konusundaki araştırmaların sıklıkla çalıșıldığı görülmüştür. Araştırmalarda nicel yöntemin, tarama deseninin, anketlerin veya ölçeklerin, amaçsal örnekleme tekniğinin en çok kullanıldığı saptanmıştır. Lisans düzeyindeki çalışmaların sıklıkla görüldüğü, yetişkinlere ve lisansüstü öğrencilere yönelik çalıșmaların ise sınırlı olduğu belirlenmiștir. Araştırma sonucunda, eğitim teknolojisi, etkileşim ile tasarım ve geliştirme konularındaki çalışmaların arttırılabileceği düşünülmektedir.

Anahtar sözcükler: Eğitim araştırmaları, eğitim araştırmalarında mevcut durum, 2017 eğitim eğilimleri, durum analizi, Ulakbim dergileri.

${ }^{1} \mathrm{Bu}$ çalışma, 27. Uluslararası Eğitim Bilimleri Kongresi'nde, 18-22 Nisan 2018 Antalya'da özet bildiri olarak sunulmuștur.

${ }^{2}$ Sorumlu Yazar: Öğr. Gör. Dr., Uzaktan Eğitim Meslek Yüksekokulu, Bilgisayar Kullanımı Bölümü, Eposta: betulozaydin@isparta.edu.tr, https://orcid.org/0000-0002-2011-1352 
İnsana ve eğitime verilen değerin her geçen gün arttığı bu artışa paralel olarak bilgi ve iletişim teknolojisinde yeniliklerin yaşandığ bilinmektedir. 21. yüzyılda bilgi ve iletişim teknolojilerinde ortaya çıkan gelişmeler, bireylerden beklenen davranışları yirminci yüzyıla göre değiştirmiş (Dede, 2010), öğrencilerden akademik içeriği bilmelerinin yanı sıra yaşamları boyunca öğrenmeyi devam ettirmeleri, bildiklerini etkili ve yenilikçi şekilde kullanmaları beklenmeye başlamıştır (Partnership for $21^{\text {st }}$ Century Skills-P21, 2006). Bu yüzyılda beklenen beceriler farklı çalışmalarda farklı biçimlerde belirtilmiştir (North Central Regional Educational Laboratory-NCREL ve Metiri Group, 2003; P21, 2006). Bu çalışmalarda eğitim açısından genel olarak, eleştirel düşünme, sorun çözme, iletişim, yaratıcılık, işbirliği, bağlamsal öğrenme, teknolojiyi anlama ve kullanma becerilerinin beklendiği görülmüştür. Eğitimde asıl amaç, bulunduğumuz yüzyılın gerekliliği olan davranışların öğrencilere kazandırılmasıdır (Collwill ve Gallagher, 2007). 2000'li yıllarda değişen beceri beklentisi, eğitim alanına yansımış ve öğrencilerden eleştirel düşünen, sorun çözebilen, akranları ve öğretmenleri ile iletişim kurabilen, birlikte çalışma yapabilen ve eğitim yaşamıyla teknolojiyi bütünleştiren bireyler durumuna gelmeleri beklenmeye başlanmıştır. $\mathrm{Bu}$ durum eğitim alanında yapılan çalışmalarda da değişikliklerin görülmesini sağlamıştır. Örneğin eğitim anlayışında pozitivizm paradigmasından pozitivizm ötesi paradigmaya yönelme olduğu, örgün öğrenme ortamına uzaktan eğitim ortamının eklendiği bilinmektedir. Araştırmacılar için son derece önemli olan bu değişiklikler, günün gerekliliklerini izleyen araştırmacıların bu yönde çalışmalar yapması anlamına gelmektedir. Hangi alanda yapılırsa yapılsın bilimsel araştırmaların, bulunduğu alana büyük katkı sağladığı bilinmektedir. Öğrencinin daha da önemli görüldüğü günümüzde; bireylerin algıları, psikolojik durumları, eğitimleri için kullanılan materyallerin, programların değerlendirilmesi ve geliştirilmeye çalışılmasının önemli olduğu düşünülmektedir. Eğitim araştırmalarının, eğitim-öğretim sürecinin biçimlendirilmesinde rol aldığı göz önünde bulundurulduğunda (Göktaş, Hasançebi, ve diğ., 2012) bu çalışmaların incelenmesi gerektiği sonucuna ulaşılmaktadır.

Farklı alanlarda mevcut çalışmaların incelendiği araştırmaların olduğu görülmektedir. Eğitim teknolojileri (Göktaş, Küçük ve diğ., 2012; Hung ve Zhang, 2012; Kılıç Çakmak ve diğ., 2015; Şimşek ve diğ., 2009), bilgisayar ve öğretim teknolojileri (Bardakçı, Kılıçer ve Özeke, 2017; Gökoğlu, Erdemir, Öztürk ve Çakıroğlu, 2014; Üstündağ, 2013), fen eğitimi (Lin, Lin ve Tsi, 2014; Sözbilir ve Kutu, 2008; Sözbilir ve diğ., 2015; Tsai ve Lydia Wen, 2005), matematik eğitimi (Aztekin ve Şener, 2015; Ulutaş ve Ubuz, 2008), eğitim programları ve öğretimi (Ozan ve Köse, 2014; Uyar, 2017), uzaktan eğitim (Lee, Driscoll ve Nelson, 2010; Zawacki-Richter, Baecker ve Vogt, 2009) gibi farklı alanlarda çalışmalara rastlamak olanaklıdır. Bunun yanı sıra eğitim alanında farklı dergileri inceleyen araştırmaların da olduğu görülmektedir (Alper ve Gülbahar, 2009; Northup, Vollmer ve Serrett, 1993; Sulzer-Azaroff ve Gillat, 1990; Turan, Karadağ, Bektaş ve Yalçın, 2014). Ayrıca eğitim bilimleri alanındaki genel eğilimin görülmesi amacı ile yapılmış olan eğilim çalışmaları da bulunmaktadır (Arık ve Türkmen, 2009; Erdem, 2011; 
Fazlıogulları ve Kurul, 2012; Göktaş, Hasançebi ve diğ., 2012; Telli ve Yurdugül, 2012; Yalçin, Yavuz ve Dibek, 2016).

Arık ve Türkmen (2009), SSCI'da dizinlenen ve Türkiye'de yayımlanmakta olan eğitim bilimleri ile ilgili dört derginin 2008 yılında yayımlanan makalelerini incelemiştir. Makaleler; konu alanı, kurum, kaynakça sayısı, araştırma türü, katılımcı özellikleri, katılımcı seçimi, değişken sayısı, kullanılan ölçek, ölçeğin özgünlüğü ve analiz türü açıssından değerlendirilmiştir. Erdem (2011), Ulakbim ulusal indeks tarafindan dizinlenen 2005-2006 yıllarında yayımlanmış olan ve dergilerinden tesadüfî olarak seçilen 8 dergideki makaleleri araştırma türü, modeli, veri toplama aracı, örneklem yöntemi ve veri çözümleme yöntemi açısından incelemiştir. Göktaş, Hasançebi ve diğ. (2012) 2005-2009 yıllarında Türkiye'de ULAKBİM ve SSCI veri tabanlarında dizinlenen eğitim dergileri araştırmalarını; yöntemleri, türleri, konu alanları, örneklem özellikleri gibi bazı açılardan değerlendirmiştir. Telli ve Yurdugül (2012), 2009-2011 yıllarında Ulakbim'de dizinlenen eğitim bilimleri alanındaki dergilerinde yayımlanan makaleleri, örnekleme yöntemleri açısından incelemiş̧ir. Karadağ (2009) ülkemizde eğitim bilimleri alanındaki doktora tezlerini incelemiştir. Yalçın ve diğ. (2016) ise 2009-2014 y1llarında beş yılın içinde etki faktörleri en yüksek olan eğitim bilimleri alanındaki uluslararası dergilerde yayımlanan makaleleri, konu alanları, veri analiz yöntemleri, yapılma nedenleri, örneklem özellikleri, çalışma grubu, veri toplama araçları ve kullanılan programlar açısından incelemiştir. Bu çalışmaların farklı indekslerde dizinlenen dergilerde, bir yıl, iki yıl, üç yıl veya beş yıllık süreçlerde gerçekleştirildiği belirlenmiştir. Araştırmalarda genellikle aynı temaların incelendiği ve yakın sonuçlara ulaşıldığı görülmektedir. Bu araştırmalar hem eğitim alanında neler çalışıldığının bir göstergesi hem de yapılacak yeni çalışmaların biçimlenmesinde yararlı birer kaynak olarak düşünülmektedir.

Araştırmacıların, önceki araştırma sonuçları hakkında kuşkucu olması, önceki çalışmaları genişletmek istemesi veya diğer araştırmacıların ne yaptığından haberdar olmaması nedeni ile aynı sorun ya da hipotez ile ilgili çalışma sayısı artmaktadır (Cooper ve Hedges, 2009). Bu nedenle araştırmacıların yaptığı çalışmaların bilinmesi önem taşımaktadır. Böylece araştırmacıların yapılan çalışmalardan haberdar olması ve çalışmalarına bu şekilde yön vermesi sağlanabilir. 2017 yılında eğitim bilimleri alanında yapılan çalışmaların konularının ve yöntemlerinin durum tespiti ile ilgili bir bulguya rastlanamamıştır. $\mathrm{Bu}$ araştırmada, Ulakbim TR dizinde sosyal ve beşeri bilimler veri tabanı dergi listesinde eğitim bilimleri alanında dizinlenen dergilerde 2017 yılında yayımlanan makaleler incelenmiştir. Böylece eğitim bilimleri alanında yapılan çalışmaların durumlarının ortaya çıkarılması, başka bir deyişle hangi konu ile ilgili çalışmaların hangi yöntemler ile yapıldığının belirlenmesi amaçlanmıştır. $\mathrm{Bu}$ amaç doğrultusunda makalelerin; daha önce bildiri olarak sunulma ya da tez olarak çalışılma durumu, araştırma yöntemi, yayına kabul süresi, yazar sayısı, örneklem sayısı, makale konusu, örneklem düzeyi ve deseni, veri toplama araçları, veri analiz yöntemi, yazım dili ve örneklem tekniği incelenmiş̧ir. Bu süreçte Türkiye'de Ulakbim tarafindan taranan dergilerde yayımlanan makalelerin incelenmesinin nedeni ise, bu dergilerdeki araştırmaların, yapılacak diğer çalışmalara ve uygulamalara yön 
verici olduğunun düşünülmesi ve TÜBİTAK Ulakbim Türkiye Dergileri dizininin belli ölçütleri olan dergileri içeren bir dizin olmasıdır.

\section{Yöntem}

Yapılan çalışmanın modeli, çalışmanın evren/örneklem bilgisi, kullanılan veri toplama aracı, güvenirlik için yapılanlar ve verilerin analizi konusunda bu bölümde bilgi verilmiştir.

\section{Araştırma Modeli}

$\mathrm{Bu}$ araştırmada, eğitim bilimleri alanında son on yıldır yayımlanmaya devam eden 14 derginin 2017 yılında yayımlamış olduğu makalelerin incelenmesinde içerik analizi yöntemi kullanılmıştır. İcerik analizi, belli bir konu ya da amaca yönelik olarak yapılan çalışmaların birlikte incelenmesi ve sonuçlarından bir senteze ulaşılması amacını taşımaktadır (Büyüköztürk, Kılıı̧-Çakmak, Akgün, Karadeniz ve Demirel, 2012).

\section{Evren-Örneklem}

2018 yılında Ulakbim TR dizinde sosyal ve beşeri bilimler veri tabanı dergi listesinde eğitim bilimleri alanında dizinlenen toplam 52 dergide 2017 yllında yayımlanmış olan makaleler, bu çalışmanın evrenini oluşturmaktadır. Ancak çalışmada eğitim bilimleri alanında genel olarak ne tür çalışmalar yapıldığını belirlemek amacı bulunduğu için spor bilimleri, özel eğitim fen ve matematik eğitimi gibi sadece bir alana yönelik olan makalelerin yer aldığı dergiler örnekleme alınmamıştır. Örneklemi, en az on yıldır (2008'den önce) yayın yaşamına devam eden eğitim bilimleri dergileri oluşturmaktadır. Bu ölçütleri taşıyan dergiler ve bunların yayın yaşamına başladığı tarih aşağıda görüldüğü gibidir:

Ankara Üniversitesi Eğitim Bilimleri Fakültesi Dergisi (1968)

Eğitim ve Bilim (1976)

Gazi Üniversitesi Gazi Eğitim Fakültesi Dergisi (1985)

Hacettepe Üniversitesi Eğitim Fakültesi Dergisi (1986)

Uludağ Üniversitesi Eğitim Fakültesi Dergisi (1987)

Kuram ve Uygulamada Eğitim Yönetimi (1995)

Kastamonu Üniversitesi Kastamonu Eğitim Dergisi (1995)

Erzincan Üniversitesi Erzincan Eğitim Fakültesi Dergisi (1999)

Ege Eğitim Dergisi (2001)

İlköğretim Online (elektronik) (2002)

İnönü Üniversitesi Eğitim Fakültesi Dergisi (2002)

Ondokuz Mayıs Üniversitesi Eğitim Fakültesi Dergisi (2004)

Yüzüncü Yıl Üniversitesi Eğitim Fakültesi Dergisi (2004)

Mersin Üniversitesi Eğitim Fakültesi Dergisi (2005)

Belirlenen özellikleri taşıyan yukarıdaki 14 derginin 2017 yılında yayımlamış olduğu toplam 830 makale araştırmanın örneklemini oluşturmaktadır. 


\section{Veri Toplama Araçları}

Veri toplama amacı ile veri toplama formu oluşturulmuştur. $\mathrm{Bu}$ form oluşturulmadan, daha önce yapılmış olan eğilim çözümlemeleri çalışmaları incelenmiş ve bazı çalışmalardan (Babur ve diğ., 2016; Fazlıogulları ve Kurul, 2012; Gökmen ve diğ., 2017; Kılıç Çakmak ve diğ., 2015; Sözbilir ve Kutu, 2008; Şimşek ve diğ., 2009; Üstündağ, 2013; Yalçın ve diğ., 2016) yararlanarak yeni bir form geliştirilmiştir. Bu formda; makale adı, makalenin basıldığı derginin adı, basım yılı, yazar sayısı, makalenin daha önce bir yerde yayımlanma durumu (bildiride sunulması ya da yazarın tezi olması), makalenin yayına kabul süresi, makale konusu, araştırma yöntemi ve deseni, örneklem düzeyi, örneklem tekniği, örneklem sayısı, makalenin dili, kullanılan veri toplama araçları ve veri analizi yöntemi yer almaktadır.

\section{Güvenirlik}

Çalışmada güvenirliği sağlamak amacıyla farklı dergilerde yayımlanmış olan on dört makale hem araştırmacı hem de başka bir araştırmacı tarafından analiz edilmiştir. $\mathrm{Bu}$ analiz sonucunda puanlayıcılar arası uyum yüzdesi \% 87 olarak bulunmuştur. Ayrıca araştırmacı farklı dergilerde yayımlanan 30 makaleyi iki hafta ara ile tekrar analiz etmiş ve uyum yüzdesi \% 94 olarak belirlenmiştir. Tavşancıl ve Aslan'ın (2001) belirttiği gibi puanlayıcılar arası ve puanlayıcılar içi güvenirliğin \% 70’ten yüksek olmasının güvenirliğin bir kanıtı olduğu göz önünde bulundurulduğunda, araştırmada belirlenen uyum yüzdelerinin yüksek olduğu görülmektedir.

\section{Verilerin Analizi}

Çalışmada, belirlenen 830 makale veri toplama formu kullanılarak incelenmiştir. İnceleme sürecinde yöntem olarak içerik analizi ve betimsel analiz kullanılmıştır. Betimsel analiz, verilerin önceden belirlenen temalara göre analiz edilmesidir. İçerik analizinde ise veriler önce kavramsallaştırılmakta daha sonra bu kavramlara göre düzenlenme ve temaların oluşturulması gerçekleştirilmektedir (Yıldırım ve Şimşek, 2008). Makale konusu, incelenen makalelerden yola çıkılarak araştırmacı tarafından belirlenen kategorileri içermektedir. Bu kategoriler ve içerdikleri anlamlar şu şekildedir:

Eğitimde ölçme ve değerlendirme. Bireylerin başkaları tarafından değerlendirilmesi, öğrenci ve öğretmen yeterliliği, eğitim sürecinin, öğretim sisteminin, denetim sisteminin, dersin, ünitenin, müfredatın, eğitim modelinin ve sınav sisteminin değerlendirilmesi, kitap, tez, makale, sınav sorusu, ödev ve form gibi materyallerin değerlendirilmesi söz konusudur.

Eğitimde psikolojik hizmetler. Bireylerdeki alg1, bireylerin görüşleri, herhangi bir konudaki farkındalıkları, öz yeterlilik inançları, hazırbulunuşlukları, bireylerin kendilerini değerlendirmesi, başkaları hakkındaki metaforlara yönelik çalışmaların, kaygı, bağlılık, bağımlılık, merhamet, umutsuzluk, tükenmişlik, mobing, stres, şiddet, çatışma, saldırganlık vb. bireylerin psikolojisine bağlı durumların konu alındığ makalelerdir. 
Öğrenme-öğretme-değerlendirme yaklaşımları, yöntemleri ve teknikleri. Öğrenme öğretme sürecinde kullanılan yöntem, yaklaşım ve tekniklerin yer aldığ çalışmaların konu alındığı makaleleri içermektedir.

Eğitim yönetimi. İş doyumu, iş yaşam kalitesi, örgütsel adalet, örgüt kültürü, eğitim ortamı, eğitim ortamındaki sorunlar ve etkileşim gibi çalışmaları içermektedir.

Eğitim teknolojisi. Bilgisayar destekli eğitim, öğrenme/öğretme araçları, eğitim yazılımı, eğitsel web sitesi, arttırılmış gerçeklik, teknoloji liderliği, bilişim teknolojileri, sosyal ağlar, siber zorbalık ve siber güvenlik çalışmaları, matematik okuryazarlığı, finansal okuryazarlık, medya okuryazarlığ 1 ile tasarım ve geliştirme gibi konuları içermektedir.

Diğer konular. Çevre, çevre kirliliği, eş seçimi, girişimcilik, beslenme, kimlik stili, otizm gibi çalışma konularını içermektedir.

\section{Bulgular}

Çalışma kapsamında incelenen 14 dergideki 830 makelenin; yazarı tarafından daha önce çalışılmış olma durumu, makale kabul süresi, yazar sayısı, makale konusu,veri toplama araçları, araştırma yöntemi ve deseni örneklem düzeyi, veri analiz yöntemi, sayısı ve tekniği ile makalenin diline ait bulgular aşağıda verilmiştir. Dergi isimlerinin uzun olması nedeni ile dergi isimlerinin baş harfleri kullanılarak parantez içinde görüldüğü gibi kısaltmalar kullanılmıştır.

Ankara Üniversitesi Eğitim Bilimleri Fakültesi Dergisi (AÜEBFD),

Eğitim ve Bilim (EB),

Ege Eğitim Dergisi (EED),

Erzincan Üniversitesi Erzincan Eğitim Fakültesi Dergisi (EÜEEFD),

Hacettepe Üniversitesi Eğitim Fakültesi Dergisi (HÜEFD),

İnönü Üniversitesi Eğitim Fakültesi Dergisi (IÜEFD),

İlköğretim Online (İO),

Kastamonu Üniversitesi Kastamonu Eğitim Dergisi (KÜKED),

Kuram ve Uygulamada Eğitim Yönetimi (KUEY),

Mersin Üniversitesi Eğitim Fakültesi Dergisi (MÜEFD),

On dokuz Mayıs Üniversitesi Eğitim Fakültesi Dergisi (OÜEFD),

Uludağ Üniversitesi Eğitim Fakültesi Dergisi (UÜEFD),

Yüzüncü Yıl Üniversitesi Eğitim Fakültesi Dergisi (YYÜEFD),

Gazi Üniversitesi Gazi Eğitim Fakültesi Dergisi (GÜGEFD).

İncelenen makalelerin, yayımlanmadan önce bildiri olarak sunulmuş olma durumu, ya da yazarın lisansüstü tezine ait olma durumu Tablo 1'de görülmektedir. 
Tablo 1

Makalelerin Yayımlanmadan Önce Çalıșlma Durumu

\begin{tabular}{|c|c|c|c|c|c|c|c|c|c|c|c|}
\hline \multirow[t]{2}{*}{$\begin{array}{l}\text { Derginin } \\
\text { Adı }\end{array}$} & \multirow{2}{*}{$\ddot{z}$} & \multicolumn{2}{|c|}{ 昰 } & \multicolumn{3}{|c|}{ 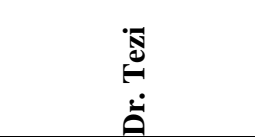 } & \multicolumn{2}{|l|}{ 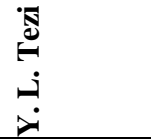 } & \multicolumn{2}{|c|}{ 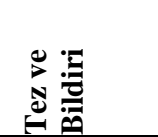 } & \multirow[t]{2}{*}{ 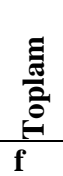 } \\
\hline & & $\%$ & f & $\%$ & f & $\%$ & f & $\%$ & f & $\%$ & \\
\hline AÜEBFD & 10 & 2.06 & 4 & 2.47 & 3 & 3.37 & 2 & 2.56 & - & & 19 \\
\hline EED & 18 & 3.71 & 14 & 8.64 & 1 & 1.12 & 2 & 2.56 & - & & 35 \\
\hline EB & 37 & 7.63 & 11 & 6.79 & 20 & 22.47 & 10 & 12.82 & 2 & 12.50 & 80 \\
\hline EÜEEFD & 27 & 5.57 & 12 & 7.41 & 8 & 8.99 & 4 & 5.13 & 2 & 12.50 & 53 \\
\hline HÜEFD & 27 & 5.57 & 12 & 7.41 & 10 & 11.24 & 9 & 11.54 & 2 & 12.50 & 60 \\
\hline İO & 72 & 14.85 & 18 & 11.11 & 9 & 10.11 & 9 & 11.54 & 3 & 18.75 & 111 \\
\hline İÜEFD & 38 & 7.84 & 15 & 9.26 & 7 & 7.87 & 1 & 1.28 & 1 & 6.25 & 62 \\
\hline KÜKED & 120 & 24.74 & 19 & 11.73 & 7 & 7.87 & 10 & 12.82 & 1 & 6.25 & 157 \\
\hline KUEY & 22 & 4.54 & - & & - & & - & & - & & 22 \\
\hline MÜEFD & 25 & 5.15 & 24 & 14.81 & 12 & 13.48 & 13 & 16.67 & 1 & 6.25 & 75 \\
\hline OÜEFD & 12 & 2.47 & 2 & 1.23 & 2 & 2.25 & 1 & 1.28 & 1 & 6.25 & 18 \\
\hline UÜEFD & 18 & 3.71 & 10 & 6.17 & 2 & 2.25 & 4 & 5.13 & 2 & 12.50 & 36 \\
\hline YYÜEFD & 36 & 7.42 & 8 & 4.94 & 5 & 5.62 & 11 & 14.10 & - & & 60 \\
\hline GÜGEFD & 23 & 4.74 & 13 & 8.03 & 3 & 3.36 & 2 & 2.57 & 1 & 6.25 & 42 \\
\hline Toplam & 485 & 100 & 162 & 100 & 89 & 100 & 78 & 100 & 16 & 100 & 830 \\
\hline
\end{tabular}

Akademik özendirme ödeneğinin gündeme gelmesi ile makalelerin birden fazla yerde kullanıldığı düşünülmeye başlamıştır. Bu amaçla Tablo 1'de görüldüğü gibi, makalelerin daha önce bildiri olarak sunup sunulmadığı ya da tezden üretilen bir makale olup olmadığı incelenmiştir. Tablo 1'e göre 830 makalenin 162'si yayımlanmadan önce bildiri olarak sunulmuştur. 89 makale yazarların doktora tez çalışmasına ait, 78 makale ise yüksek lisans tezine ait çalışmalardır. Lisansüstü çalışmaların, bildiri olarak da sunulduktan sonra yayımlandığı 16 çalışma bulunmaktadır. Çalışmaların 485'inin (\% 58.43) ise ilk kez çalışıldığı görülmektedir.

Makalelerin dergilere gönderilmesi ile yayına kabul edilmesi arasında geçen süre Tablo 2'de görülmektedir.

Tablo 2

Makalenin Yayına Kabul Süresi

\begin{tabular}{|c|c|c|c|c|c|c|c|c|c|c|c|}
\hline Derginin adı & & $\begin{array}{l}\overline{\mathrm{J}} \\
\text { है } \\
- \text { त }\end{array}$ & & 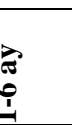 & & $\begin{array}{l}\vec{c} \\
\frac{1}{1} \\
\frac{1}{1}\end{array}$ & & $\begin{array}{l}\vec{\jmath} \\
\infty \\
\vec{\sigma} \\
\dot{\sigma}\end{array}$ & & 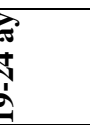 & 뭉 \\
\hline & $\mathrm{f}$ & $\%$ & f & $\%$ & f & $\%$ & f & $\%$ & f & $\%$ & f \\
\hline AÜEBFD & - & - & 11 & 2.30 & 3 & 1.27 & 4 & 6.78 & 1 & 5.88 & - \\
\hline EED & - & - & 31 & 6.49 & 4 & 1.69 & - & - & - & - & - \\
\hline EB & - & - & 35 & 7.32 & 26 & 10.97 & 12 & 20.34 & 6 & 35.29 & - \\
\hline
\end{tabular}


Tablo 2 (devam)

\begin{tabular}{|c|c|c|c|c|c|c|c|c|c|c|c|}
\hline $\begin{array}{l}\text { Derginin } \\
\text { adı }\end{array}$ & & 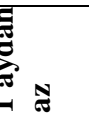 & & 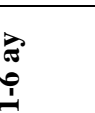 & & $\begin{array}{l}\overrightarrow{3} \\
\stackrel{3}{1} \\
\frac{1}{n}\end{array}$ & & $\vec{a}$ & & $\vec{a}$ & क्षे \\
\hline EÜEEFD & - & - & 48 & 10.04 & 5 & 2.11 & - & - & - & - & - \\
\hline HÜEFD & 1 & 12.50 & 37 & 7.74 & 8 & 3.38 & 8 & 13.56 & 4 & 23.53 & - \\
\hline İO & 1 & 12.50 & 53 & 11.09 & 43 & 18.14 & 8 & 13.56 & 3 & 17.65 & 2 \\
\hline İÜEFD & - & - & 33 & 6.90 & 24 & 10.13 & 5 & 8.47 & - & - & - \\
\hline KÜKED & 3 & 37.50 & 79 & 16.53 & 48 & 20.25 & 17 & 28.82 & 3 & 17.65 & 7 \\
\hline KUEY & - & - & - & - & 22 & 9.28 & - & - & - & - & - \\
\hline MÜEFD & - & - & 37 & 7.74 & 36 & 15.19 & 2 & 3.39 & - & - & \\
\hline OÜEFD & - & - & - & - & - & - & - & - & - & - & 18 \\
\hline UÜEFD & 1 & 12.50 & 22 & 4.60 & 12 & 5.06 & 1 & 1.69 & - & - & - \\
\hline YYÜEFD & 1 & 12.50 & 52 & 10.88 & 4 & 1.69 & 2 & 3.39 & - & - & 1 \\
\hline GÜGEFD & 1 & 12.50 & 40 & 8.37 & 2 & .84 & 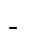 & - & - & - & \\
\hline Toplam & 8 & 100 & 478 & 100 & 237 & 100 & 59 & 100 & 17 & 100 & 28 \\
\hline
\end{tabular}

Genel olarak 1-6 ay arasında yoğunluk olduğu belirlenmiştir. Bunun yanı sıra 1 aydan daha az sürede kabul edilen ve 25 aydan daha uzun sürede kabul edilen yayınlar da bulunmaktadır. Yayının kabul süresinin her bir dergide ayrı yoğunlukta olduğu görülmektedir. Örneğin KUEY dergisinde yayımlanan makalelerin 7-12 ay arasında kabul edildiği belirlenmiştir. 28 makalenin ise gönderilme tarihinin ve kabul tarihinin belli olmadığı görülmektedir. Tabloya eklenmeyen ancak HÜEFD'de 2 tane, İO'da ise 1 tane makalenin 25 aydan fazla sürede yayına kabul edildiği belirlenmiştir. Tablo 3 ise makalelerdeki yazar sayısını göstermektedir.

Tablo 3

Makalelerdeki Yazar Sayıs

\begin{tabular}{|c|c|c|c|c|c|c|c|c|c|c|c|c|}
\hline \multirow{2}{*}{$\begin{array}{l}\text { Derginin } \\
\text { Adı }\end{array}$} & \multirow{2}{*}{$\frac{1}{f}$} & \multicolumn{3}{|c|}{2} & \multicolumn{2}{|l|}{3} & \multicolumn{2}{|l|}{4} & \multicolumn{2}{|c|}{$5-8$} & \multicolumn{2}{|c|}{ Toplam } \\
\hline & & $\%$ & f & $\%$ & f & $\%$ & f & $\%$ & f & $\%$ & f & $\%$ \\
\hline$\overline{\mathrm{AÜEBFD}}$ & 8 & 42.11 & 8 & 42.11 & 2 & 10.53 & 1 & 5.26 & - & & 19 & 100 \\
\hline EED & 5 & 14.29 & 18 & 51.43 & 9 & 25.71 & 3 & 8.57 & - & & 35 & 100 \\
\hline EB & 23 & 28.75 & 43 & 53.75 & 9 & 11.25 & 4 & 5.00 & 1 & 1.25 & 80 & 100 \\
\hline EÜEEFD & 12 & 22.64 & 29 & 54.72 & 8 & 15.09 & 4 & 7.55 & - & & 53 & 100 \\
\hline HÜEFD & 11 & 18.33 & 31 & 51.67 & 14 & 23.33 & 4 & 6.67 & - & & 60 & 100 \\
\hline İO & 24 & 21.62 & 63 & 56.76 & 19 & 17.12 & 3 & 2.70 & 2 & 1.80 & 111 & 100 \\
\hline İÜEFD & 20 & 32.26 & 26 & 41.94 & 14 & 22.58 & - & - & 2 & 3.23 & 62 & 100 \\
\hline KÜKED & 48 & 30.57 & 76 & 48.41 & 22 & 14.01 & 7 & 4.46 & 4 & 2.55 & 157 & 100 \\
\hline KUEY & 5 & 22.73 & 15 & 68.18 & 1 & 4.55 & 1 & 4.55 & - & & 22 & 100 \\
\hline MÜEFD & 18 & 24.00 & 48 & 64.00 & 8 & 10.67 & 1 & 1.33 & - & & 75 & 100 \\
\hline OÜEFD & 3 & 16.67 & 11 & 61.11 & 3 & 16.67 & 1 & 5.56 & - & & 18 & 100 \\
\hline UÜEFD & 8 & 22.22 & 23 & 63.89 & 3 & 8.33 & 1 & 2.78 & 1 & 2.78 & 36 & 100 \\
\hline YYÜEFD & 14 & 23.33 & 34 & 56.67 & 9 & 15.00 & 3 & 5.00 & - & & 60 & 100 \\
\hline GÜGEFD & 9 & 21.43 & 19 & 45.24 & 12 & 28.57 & 1 & 2.38 & 1 & 2.38 & 42 & 100 \\
\hline Toplam & 208 & & 444 & & 133 & & 34 & & 11 & & 830 & \\
\hline
\end{tabular}


Tablo 3'te ise yayımlanan makalelerde yazar sayısının 1 ile 8 arasında olduğu görülmektedir. En çok $(n=444)$ iki yazarlı ve tek yazarlı $(n=208)$ yayınların olduğu belirlenmiştir. Ayrıca beş ve daha fazla yazarlı çalışma sayısının ise 11 olduğu görülmektedir. AÜEBFD'de yayımlanan 19 makaleden 8'inin (\% 42.11) tek yazarlı olduğu, 8'inin (\% 42.11) iki yazarlı olduğu görülmektedir. Tablo 4'te görüldüğü gibi makale konuları altı kategori altında toplanmıştır.

Tablo 4

Makale Konusu

\begin{tabular}{lcc}
\hline Makale Konusu & f & $\mathbf{\%}$ \\
\hline Eğitimde ölçme ve değerlendirme & 343 & 41.33 \\
Eğitimde psikolojik hizmetler & 177 & 21.33 \\
Öğrenme-öğretme-değerlendirme yaklaşımları, yöntemleri ve teknikleri & 160 & 19.28 \\
Eğitim yönetimi & 75 & 9.04 \\
Eğitim teknolojisi & 61 & 7.34 \\
Diğgr & 14 & 1.68 \\
\hline Toplam & 830 & 100 \\
\hline
\end{tabular}

Tablo 4'te en çok eğitimde ölçme ve değerlendirme konusunda çalışma yapıldığı, bu konuda 343 makale olduğu görülmektedir. İkinci sırada ise makalelerin \% 21.33'ünü oluşturan 177 makale ile eğitimde psikolojik hizmetler konulu çalışmaların olduğu belirlenmiştir. En az çalışılan konu ise diğer başlığg altında bulunan konuların olduğu görülmekte ve tüm çalışmaların \% 1.69'unu oluşturmaktadır. Ayrıca tabloda yer almamasına karşın eğitim yönetimi başlığı altında yer alan etkileşim konusunun tüm çalışmaların \% 1.11'ini, eğitim tekonolojisi altında yer alan tasarım ve geliştirme konusunun ise \% 0.80'ini oluşturduğu ve ez an çalışılan konular olduğu saptanmıştır.

Tablo 5'te makalelerin araștırma yöntemi ve deseni görülmektedir. Bu tablo bazı çalışmalardan yararlanarak (Böke, 2009; Büyüköztürk, Akgün, Kahveci ve Demirel, 2004) incelenen makaleler doğrultusunda oluşturulmuştur.

Tablo 5

Araştırma Yöntemi ve Deseni

\begin{tabular}{|c|c|c|c|c|c|}
\hline \multirow[t]{2}{*}{ Yöntem } & \multirow[t]{2}{*}{ Desen } & \multirow[t]{2}{*}{$\mathbf{f}$} & \multirow[t]{2}{*}{$\%$} & \multicolumn{2}{|c|}{ Toplam } \\
\hline & & & & f & $\%$ \\
\hline \multirow[t]{5}{*}{ Deneysel olmayan } & Tarama & 268 & 32.29 & 393 & 47.35 \\
\hline & Korelasyon & 19 & 2.29 & & \\
\hline & Nedensel Karşılaştırmalı & 10 & 1.20 & & \\
\hline & Meta analiz & 9 & 1.08 & & \\
\hline & Diğer (temel araştırma) & 3 & 0.36 & & \\
\hline
\end{tabular}


Tablo 5 (devam)

\begin{tabular}{|c|c|c|c|c|c|}
\hline \multirow[t]{2}{*}{ Yöntem } & \multirow[t]{2}{*}{ Desen } & \multirow[t]{2}{*}{$\mathbf{f}$} & \multirow[t]{2}{*}{$\%$} & \multicolumn{2}{|c|}{ Toplam } \\
\hline & & & & $f$ & $\%$ \\
\hline \multirow[t]{6}{*}{ Deneysel } & Yarı Deneysel & 38 & 4.58 & & \\
\hline & Gerçek Deneysel & 34 & 4.10 & & \\
\hline & Faktöriyel Desen & 5 & 0.60 & & \\
\hline & Zayıf Deneysel & 3 & 0.36 & & \\
\hline & Diğer (Solomon Dört Gruplu) & 2 & 0.24 & & \\
\hline & Tek denekli & 2 & 0.24 & & \\
\hline \multirow[t]{10}{*}{ Nitel } & Durum çalışması & 99 & 11.93 & 278 & 33.49 \\
\hline & Doküman analizi & 52 & 6.27 & & \\
\hline & Olgu bilim & 46 & 5.54 & & \\
\hline & Belirtilmemiş & 43 & 5.18 & & \\
\hline & Eylem araştırması & 13 & 1.57 & & \\
\hline & Betimsel & 12 & 1.45 & & \\
\hline & Anlatı Deseni & 3 & 0.36 & & \\
\hline & Kültür Analizi & 2 & 0.24 & & \\
\hline & Kuram oluşturma & 1 & 0.12 & & \\
\hline & $\begin{array}{l}\text { Diğer (Desen tabanll, Heuristik } \\
\text { yaklaşım vb.) }\end{array}$ & 7 & 0.84 & & \\
\hline \multirow[t]{3}{*}{ Karma } & Çeşitleme & 44 & 5.30 & 61 & 7.35 \\
\hline & Açıklayıcı & 12 & 1.45 & & \\
\hline & Keşfedici & 5 & 0.60 & & \\
\hline \multirow{2}{*}{$\begin{array}{l}\text { Araç geliştirme ve } \\
\text { uyarlama }\end{array}$} & Mevcut araci uyarlama & 26 & 3.13 & 50 & 6.02 \\
\hline & Yeni araç oluşturma & 24 & 2.89 & & \\
\hline Alanyazın Derleme & $\begin{array}{l}\text { Alanyazın Derleme- } \\
\text { çalışma }\end{array}$ & 38 & 4.59 & 38 & 4.59 \\
\hline Diğer & $\begin{array}{l}\text { (Tasarım, geliştirme, simülasyon } \\
\text { vb.) }\end{array}$ & 10 & 1.20 & 10 & 1.20 \\
\hline Toplam & & 830 & 100 & 830 & 100 \\
\hline
\end{tabular}

Tablo 5'e göre, çalışmaların \% 47.35'i olan 393 çalışma nicel yöntemle yapılmış ve en çok kullanılan yöntem olmuştur. Nicel çalışmaların ardından 278 (\% 33.49) nitel çalışmanın yapıldığ 1 görülmektedir. Nicel araştırmalar içinde en çok deneysel olmayan tarama deseninin kullanıldığı ve bu çalışmaların tüm çalışmaların \% 32.29'unu oluşturduğu, nitel araştırmalarda ise en çok durum çalışması deseninin kullanılarak tüm çalışmaların \% 11.93'ünü oluşturduğu görülmektedir. Araştırma yöntemlerinden üçüncü sırada karma yöntemin olduğu ve bu yöntemde çeşitleme amacıyla yapılan 44 çalışmanın bulunduğu belirlenmiştir. En az kullanılan yöntemlerin ise nicel araştırmalarda tek denekli (\% 0.24), nitel araştırmalarda ise anlatı deseni ( $\% 0.36)$ ve kuram oluşturma (\% 0.12) olduğu görülmektedir.

Tablo 6'da makalelerde kullanılmış durumda olan veri toplama araçlarını göstermektedir. Araştırmalarda tek veri toplama aracı kullanılmadığı için toplam makale sayısından fazla olduğu görülmektedir. 
Tablo 6

Veri Toplama Araçları

\begin{tabular}{|c|c|c|c|c|}
\hline \multirow[t]{2}{*}{ Veri toplama aracı } & \multirow[t]{2}{*}{$\mathbf{f}$} & \multirow[t]{2}{*}{$\%$} & \multicolumn{2}{|c|}{ Toplam } \\
\hline & & & f & $\%$ \\
\hline Mevcut anket/ölçek & 295 & 23.34 & 295 & 23.34 \\
\hline Araştırmada geliştirilen anket/ölçek & 233 & 18.43 & 233 & 18.43 \\
\hline \multicolumn{3}{|l|}{ Görüşme formu } & \multirow{6}{*}{227} & \multirow{6}{*}{17.96} \\
\hline \multicolumn{3}{|l|}{ Bireysel } & & \\
\hline Yar1 yapılandırılmış & 169 & 13.37 & & \\
\hline Yapılandırılmış & 17 & 1.34 & & \\
\hline Yapılandırılmamış & 5 & 0.40 & & \\
\hline Odak grup & 36 & 2.85 & & \\
\hline 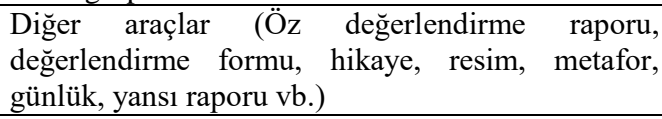 & 156 & 12.34 & 156 & 12.34 \\
\hline Başarı testi & 154 & 12.18 & 154 & 12.18 \\
\hline Gözlem formu & 92 & 7.28 & 92 & 7.28 \\
\hline Doküman & 82 & 6.49 & 82 & 6.49 \\
\hline Kayıt teknikleri (Sistem, video) & 25 & 1.98 & 25 & 1.98 \\
\hline Toplam & 1264 & 100 & 1264 & 100 \\
\hline
\end{tabular}

Tablo 6'da görüldüğü gibi en sık kullanılan araç olarak varolan, daha önceden hazırlanmış bir anketin ya da ölçeğin (\% 23.34) kullanıldığı görülmektedir. İkinci sırada (\% 18.43) araştırmada geliştirilen ölçek ve anket kullanımı gelmektedir. Görüşme formu ile yapılan veri toplama işleminin ise çalışmaların \% 17.96'lık kısmını oluşturduğu görülmektedir. Yapılandırılmamış bireysel görüşmenin (\% 0.40), sistem kaydı, video kaydı gibi kayıt tekniklerinin (\% 1.98) en az kullanılan veri toplama yöntemleri olduğu belirlenmiştir.

Tablo 7'de makalelerdeki örneklem düzeyi görülmektedir. Bazı çalışmalarda örneklem düzeyinin bir tane olmadığı daha fazla kullanıldığı gözlenmiştir.

Tablo 7

Örneklem Düzeyi

\begin{tabular}{lll}
\hline Örneklem Düzeyi & f & $\mathbf{\%}$ \\
\hline Lisans öğrencisi & 233 & 28.73 \\
\hline Öğretmen & 164 & 20.22 \\
\hline İlköğretim (1-8) öğrencisi & 147 & 18.13 \\
\hline Ortaöğretim (9-12) öğrencisi & 78 & 9.62 \\
\hline Okulöncesi öğrencisi & 40 & 4.93 \\
\hline Yönetici & 32 & 3.95 \\
\hline Öğretim Elemanı & 20 & 2.47 \\
\hline Veli & 15 & 1.85 \\
\hline & \multicolumn{2}{c}{ (devam ediyor) }
\end{tabular}


Tablo 7 (devam)

\begin{tabular}{lcc}
\hline Örneklem Düzeyi & f & $\mathbf{\%}$ \\
\hline Lisansüstü öğrencisi & 12 & 1.48 \\
\hline Yetişkin & 8 & 0.99 \\
\hline Diğer (müfettiş, çalışan, hasta, engelli, çalıştırıcı vb.) & 62 & 7.64 \\
\hline Toplam & 811 & 100 \\
\hline
\end{tabular}

Tablo 7'de çalışmaların en fazla lisans öğrencileri ile ( $\%$ 28.73) gerçekleştirildiği belirlenmiştir. Sonrasında \% 20.22'lik çalışma dilimi ile öğretmenlerin yer aldığı çalışmalar bulunmaktadır. Yetişkin örneklem düzeyinde ise 8 çalışma yer almaktadır. Ayrıca örneklem düzeyi olarak ifade edilemese de 85 çalışmada doküman incelemesi yapılmıştır. Tablo 8, örneklem sayısının kaç kişiden oluştuğunu göstermektedir.

Tablo 8

Örneklem Sayısı

\begin{tabular}{lll}
\hline Örneklem Sayısı & $\mathbf{f}$ & $\mathbf{\%}$ \\
\hline $1-10$ & 71 & 8.55 \\
\hline $11-30$ & 115 & 13.86 \\
\hline $31-50$ & 89 & 10.72 \\
\hline $51-100$ & 108 & 13.01 \\
\hline $101-200$ & 92 & 11.08 \\
\hline $201-300$ & 74 & 8.92 \\
\hline $301-400$ & 72 & 8.67 \\
\hline $401-500$ & 32 & 3.86 \\
\hline $501-600$ & 33 & 3.98 \\
\hline $701-700$ & 22 & 2.65 \\
\hline $801-900$ & 4 & 0.48 \\
\hline $901-1000$ & 6 & 0.72 \\
\hline 1000 ve üstü & 7 & 0.84 \\
\hline Belirtilmemiş & 39 & 4.70 \\
\hline Toplam & 66 & 7.96 \\
\hline & 830 & 100 \\
\hline
\end{tabular}

Tablo 8’e göre en çok 11-30 örneklem sayısı ile yapılan çalışma bulunmakta ve bu çalışmalar, tüm çalışmaların \% 13.86'sını oluşturmaktadır. Bu örneklem grubunu 51-100 arasındaki örneklem sayısının yer aldığı çalışmalar izlemektedir. 66 çalışmada ise örneklem sayısının belirtilmediği ya da örneklem sayısı vermeye uygun olmayan kuramsal çalışma gibi araştırmaların olduğu görülmektedir. Tablo 9'da ise makalelerde örneklem belirlerken kullanılan örnekleme teknikleri görülmektedir. 
Tablo 9

Örneklem Tekniği

\begin{tabular}{|c|c|c|c|c|c|}
\hline \multirow{2}{*}{\multicolumn{2}{|c|}{ Örneklem Tekniği }} & \multirow[t]{2}{*}{ f } & \multirow[t]{2}{*}{$\%$} & \multicolumn{2}{|c|}{ Toplam } \\
\hline & & & & f & $\%$ \\
\hline \multirow{3}{*}{$\begin{array}{l}\text { Seçkisiz } \\
\text { olmayan }\end{array}$} & Amaçsal (ölçüt, maksimum çeşitlilik vb.) & 212 & 25.54 & \multirow[t]{3}{*}{369} & \multirow[t]{3}{*}{44.46} \\
\hline & Uygun/kazara & 154 & 18.55 & & \\
\hline & Sistematik & 3 & 0.36 & & \\
\hline \multirow[t]{3}{*}{ Seçkisiz } & Basit & 57 & 6.87 & \multirow[t]{3}{*}{102} & \multirow[t]{3}{*}{12.29} \\
\hline & Tabakalı & 34 & 4.10 & & \\
\hline & Küme & 11 & 1.33 & & \\
\hline Belirtilmemiş & Belirtilmemiş & 157 & 18.92 & 157 & 18.92 \\
\hline Çalışma grubu & Çalışma grubu & 132 & 15.90 & 132 & 15.90 \\
\hline Uygun değil & Uygun değil & 55 & 6.62 & 55 & 6.62 \\
\hline $\begin{array}{l}\text { Evrenin } \\
\text { tamamı }\end{array}$ & Evrenin tamamı & 15 & 1.81 & 15 & 1.81 \\
\hline Toplam & & 830 & 100 & 830 & 100 \\
\hline
\end{tabular}

Tablo 9'a göre örneklem belirlerken en çok amaçsal örnekleme tekniği $(n=212)$ kullanılmıştır. Sonra 154 makalede uygun/kazara örnekleme yöntemi kullanılmıştır. 157 makalede ise kullanılan tekniğin belirtilmemiş olduğu görülmektedir. Tablo 10 'da incelenen nicel ve nitel çalışmalarda kullanılan yöntemler ayrı ayrı gruplanmıştır.

Tablo 10

Veri Analiz Yöntemi

\begin{tabular}{|c|c|c|c|c|c|c|}
\hline \multicolumn{3}{|c|}{ Veri Analiz Yöntemi } & \multirow[t]{2}{*}{$\mathbf{f}$} & \multirow[t]{2}{*}{$\%$} & \multicolumn{2}{|c|}{ Toplam } \\
\hline & & & & & & $\%$ \\
\hline \multirow{16}{*}{ Nicel } & Betimsel & Ortalama, standart sapma & 154 & 9.37 & 378 & 23.02 \\
\hline & Analiz & Frekans, yüzde değeri & 149 & 9.07 & & \\
\hline & & Çarp1klık, basıklık & 75 & 4.57 & & \\
\hline & Kestirimsel & T testi & 161 & 9.81 & 827 & 50.37 \\
\hline & & Anova & 153 & 9.32 & & \\
\hline & & Korelasyon analizi & 92 & 5.60 & & \\
\hline & & Regresyon analizi & 86 & 5.24 & & \\
\hline & & Mann Whitney U & 62 & 3.78 & & \\
\hline & & Faktör analizi & 61 & 3.71 & & \\
\hline & & Post Hoc Test & 55 & 3.35 & & \\
\hline & & Kruskal Wallis H-Testi & 33 & 2.01 & & \\
\hline & & Wilcoxon İşaretli Sıralar testi & 30 & 1.83 & & \\
\hline & & Manova/Mancova & 23 & 1.40 & & \\
\hline & & Yapısal Eşitlik modeli & 18 & 1.10 & & \\
\hline & & Ancova & 16 & 0.97 & & \\
\hline & & Ki-kare & 13 & 0.79 & & \\
\hline
\end{tabular}


Tablo 10 (devam)

\begin{tabular}{|c|c|c|c|c|c|c|}
\hline & \multirow[t]{2}{*}{ f } & \multirow[t]{2}{*}{$\%$} & \multicolumn{2}{|c|}{ Toplam } \\
\hline \multicolumn{2}{|c|}{ Veri Analız Yontemı } & & & & $\mathbf{f}$ & $\%$ \\
\hline & & Meta Analiz & 9 & 0.55 & & \\
\hline & & Path analizi & 9 & 0.55 & & \\
\hline & & Rasch analizi & 4 & 0.24 & & \\
\hline & & Chaid analizi & 2 & 0.12 & & \\
\hline & \multirow[t]{2}{*}{$\begin{array}{l}\text { Geçerlik- } \\
\text { Güvenirlik }\end{array}$} & $\begin{array}{l}\text { İç tutarlılık (alfa, madde } \\
\text { analizi) }\end{array}$ & 42 & 2.56 & 49 & 2.98 \\
\hline & & Test-tekrar test güvenirliği & 7 & 0.43 & & \\
\hline \multirow[t]{4}{*}{ Nitel } & \multicolumn{2}{|c|}{ İcerik Analizi } & 201 & 12.23 & 388 & 23.63 \\
\hline & \multicolumn{2}{|c|}{ Betimsel Analiz } & 174 & 10.60 & & \\
\hline & \multicolumn{2}{|c|}{$\begin{array}{l}\text { Açık kodlama, eksenel kodlama, seçici } \\
\text { kodlama }\end{array}$} & 7 & 0.43 & & \\
\hline & \multicolumn{2}{|c|}{$\begin{array}{l}\text { Diğer (Yorumlayıcı Fenomenolojik, odaksal } \\
\text { vb.) }\end{array}$} & 6 & 0.37 & & \\
\hline \multicolumn{3}{|c|}{ Toplam } & 1642 & 100 & 1642 & 100 \\
\hline
\end{tabular}

Nicel çalışmalar betimsel analiz ve kestirimsel analiz olarak ikiye ayrılmıştır. Nicel çalışmalarda en çok betimsel analiz kategorisinde yer alan ortalama ve standart sapma değerlerinin kullanıldığı görülmektedir. Kestirimsel analiz kategorisinde ise ilk sırada t testinin geldiği ve 161 çalışmada kullanıldığ 1 belirlenmiştir. Nicel çalışmalarda normalliği belirlemek için yapılan analizler, bazı çalı̧̧malarda açıklanmış bazılarında ise açıklanmamıştır. Bu nedenle normallikle ilgili kullanılan analiz yönetmeleri dikkate alınmamıştır. Nitel çalışmalarda ise içerik analizi $(\mathrm{n}=201)$ ve betimsel analiz $(n=174)$ en çok kullanılan analiz yöntemleridir. Tablo 11'de makalelerde hangi dilin kullanıldığı görülmektedir.

Tablo 11

Kullanılan Dil

\begin{tabular}{lll}
\hline Kullanılan Dil & f & $\mathbf{\%}$ \\
\hline Türkçe & 60 & 7.23 \\
\hline Türkçe ve Genişletilmiş İngilizce Özet & 584 & 70.36 \\
\hline İngilizce & 95 & 11.45 \\
\hline İngilizce ve Türkçe & 90 & 10.84 \\
\hline Diğer & 1 & 0.12 \\
\hline Toplam & 830 & 100 \\
\hline
\end{tabular}

Tablo 11'de ki verilere göre makalelerin \% 7.23'ü Türkçe, \% 11.45'i İngilizce, \% 70.36'sı Türkçe ve genişletilmiş İngilizce özet olarak yayımlanmıştır. Bazı dergilerin yayın politikası nedeni ile makalelerin \% 10.84'ünün her iki dilde de yayımlandığı görülmektedir. Sadece 1 makale ise Fransızca olarak yayımlanmıştır. 


\section{Tartışma, Sonuç ve Öneriler}

Eğitim bilimleri alanında 2017 yılında yapılan çalışmalardaki mevcut durumu belirlemek amacıyla Ulakbim TR dizinde sosyal ve beşeri bilimler veri tabanı dergi listesinde eğitim bilimleri alanında dizinlenen ve son on yıldır yayın sürecine devam eden 14 dergideki 830 makale incelenmiştir.

Ülkemizde 2018 yılında doçentlik başvuru koşullarında, 2019 yılında ise akademik özendirme ödeneği ve yükselme ölçütünde değişiklikler yapıldığı bilinmektedir. Yapılan inceleme sonucunda yayımlanan makalelerin yarısına yakınının, yazarın daha önce bildiri olarak sunduğu çalışmaları içerdiği ya da lisansüstü tezinden üretildiği belirlenmiştir. Bu durum, akademik özendirme ödeneği ve yükselme ölçütlerinde Ulakbim dergilerinin, diğer indeksli dergilere göre daha yüksek puan alıyor olması nedeniyle uzun süre emek harcanan çalışmaların Ulakbim dergilerine gönderildiğini düşündürmektedir.

Analizi yapılan dergilerin, makaleleri alım süresi ile hakemler tarafından incelenmesi ve kabul edilmesi arasında geçen sürenin en çok 1-6 ay arasında olduğu belirlenmiştir. Dergilerin kendi içinde de yayına kabul sürelerinde belli bir dağılım olduğu görülmektedir. Örneğin Eğitim ve Bilim Dergisinde makalelerin çoğunlukla 7-12 ay aralığında kabul aldığı, Gazi Üniversitesi Gazi Eğitim Fakültesi Dergisinde ise çoğunlukla 1-6 ay aralığında kabul aldığı belirlenmiştir. Ayrıca tabloda verilmiş olmamasına karşın yapılan incelemeler sırasında dergilere geliş yılına göre kabul süresinin değiştiği, 2015 yılında gönderilen çalışmaların uzun süre beklemesine karşın 2016 y1lında gelenlerin hızlı kabul olduğu dergilerin bulunduğu gözlenmiştir. Bu bulgu, hakem sayısının değişmiş olabileceğini akla getirmektedir. Bu sonuç ise gönderilecek yeni makalelerin, dergilerde daha kısa sürede inceleneceğini düşündürmektedir.

Makaleler en çok tek yazarlı ve iki yazarlı olarak yazılmıştır. İki yazarlı olan makale sayısı ise tüm makalelerin yarısından fazladır (444, \% 53.49). Benzer şekilde Ozan ve Köse'nin (2014) çalışmasında da en çok iki yazarlı, sonrasında tek yazarlı makaleler olduğu belirlenmiştir. Turan ve diğ.'nin (2014) araştırması ile Alper ve Gülbahar'ın (2009) çalışmasında da yazar sayısının bir ve ikide yoğunluk gösterdiği belirlenmiştir. Yani 2017 yılında yazar sayısının önceki yıllara göre farklılaşmadığı söylenebilir. Bu sonuç, doçentlik atanma ölçütlerinde 2018 yılına kadar, makale yazar sayısının puanlandırılmasında değişikliğin olmaması ile ilgili olabileceğini düşündürmektedir.

Makale konuları analizler sonucunda altı başlık altında gruplandırılmıştır. Eğitimde ölçme ve değerlendirme konusunun en çok çalışılan konu olduğu belirlenmiştir. Bu konudan sonra en çok çalışlan ikinci konu ise eğitimde psikolojik hizmetler sonrasında ise öğrenme-öğretme-değerlendirme yaklaşımları, yöntemleri ve teknikleri ile ilgili çalışmalardır. Bu konu içinde ise 21. yüzyıl beklentileri ile ilişkili olarak daha çok öğrenci merkezli yöntemlerin çalışıldığı görülmüştür. Eğitim teknolojisi ve diğer başlığında bulunan konuların ise daha az çalışıldığı saptanmıştır. 
Eğitim yönetimi içinde yer alan etkileşim, eğitim teknolojisi konusunda ise tasarım ve geliştirme konularının en az çalışılan konular arasında olduğu görülmektedir. Bu konuların da oldukça önemli olduğu bilinmektedir ancak çalışılmasının uzun süre gerektirmesi nedeniyle az sayıda çalışmanın bulunduğu düşünülmektedir. Çalışmaya benzer şekilde Ozan ve Köse'nin (2014) araştırmasında da öğrenme ve öğretme konuları ile ilgili çalışmaların en çok araştırıldığı belirlenmiştir. Bu bulgu, eğitim bilimleri alanında, öğrenme-öğretmenin her dönem en öncelikli konu olduğunu ve bu konuya ağırlık verilebileceğini düşündürmektedir.

Araştırmalarda kullanılan yöntemler içinde en çok nicel yöntem, sonra nitel yöntemin kullanıldığı belirlenmiştir. Bazı yayınlarda da (Arık ve Türkmen, 2009; Göktaş, Hasançebi ve diğ., 2012; Ozan ve Köse, 2014; Selçuk, Palanc1, Kandemir ve Dündar, 2014; Şimşek ve diğ., 2009) ilk sırada nicel, ikinci sırada nitel araştırma yönteminin kullanıldığının belirlenmesi bu veriyi desteklemektedir. Nicel çalışmalarda en çok tarama yöntemi, nitel çalışmalarda ise durum çalışmasının desen olarak seçildiği görülmüştür. Tasarım ve geliştirme gibi diğer yöntemlerin ise en az kullanıldığı belirlenmiştir. Turan ve diğ. (2014) ile Fazlıoğulları ve Kurul'un (2012) çalışmasında ise tarama modelinin en sık kullanıldığı saptanmıştır. Araştırma sonucunda birçok çalışmada olduğu gibi nicel yöntemin daha çok kullanılmış olması, nicel yöntemin daha kolay görülmesi, genellenebilir olması ve nitel çalışma kadar uzun sürmemesine bağlanabilir. Tarama yöntemi ve durum çalışmasının ilk sırada olması ise yapılan çalışmalarda durum saptamaya yönelik araştırmanın daha çok tercih edildiğini düşündürmektedir.

Veri toplama araçlarının kullanılan yöntemler ile uyumlu olduğu görülmüştür. Nicel çalışmalarda, daha sık kullanılan anketlerin ve ölçeklerin veri toplama aracı olarak da daha sık görüldüğü belirlenmiştir. Veri toplama araçlarında en çok daha önce geliştirilmiş olan anketlerin ve ölçeklerin kullanıldı̆̆ kayıtların ise en az kullanıldığı belirlenmiştir. Erdem (2011), Göktaş, Küçük ve diğ. (2012), Ozan ve Köse'nin (2014) araştırmalarında da en çok anket yolu ile veri toplandığı belirlenmiştir. Yalçın ve diğ. (2016) ise anketin en çok kullanılan ikinci veri toplama aracı olduğunu belirlemiş̧ir. Anketlerin daha sik kullanılırken sistem ve video kayıtlarının fazla tercih edilmemesi yapılan çalışmaların hızlı sonuçlandırılmak istenmesine bağlı olabilir.

Yapılan çalışmaların en çok lisans düzeyinde gerçekleştirildiği, sonrasında ise öğretmenler ile yapılan çalışmaların yer aldığı belirlenmiştir. Lisansüstü öğrencilerle ve yetişkinlerle yapılan çalışmaların ise sınırlı kaldığı görülmektedir. Bu bulgu daha fazla katılımcıya, daha kolay erişimin sağlanabildiği örneklem gruplarının tercih edildiği sonucunu ortaya çıkarmaktadır. Ozan ve Köse (2014), Göktaş, Hasançebi ve diğ.'nin (2012) araştırmasında da aynı örneklem düzeylerinin en çok tercih edildiği, Göktaş, Hasançebi ve diğ.'nin (2012) çalışmasında lisansüstü öğrenci grubunun ise en az çalışıldığı belirlenmiştir. Arık ve Türkmen'in (2009) araştırmasında ilk sırada öğrenci, sonra öğretmen ile yapılan çalışmaların geldiği görülmektedir. Yalçın ve diğ.'nin (2016) çalışmasında en çok ilköğretim ve lise öğrencileri ile ilgili çalışma 
olduğu, en az lisansüstü öğrencilerle ve akademisyenlerle ilgili çalışıldığı belirlenmiştir. Fazlıoğulları ve Kurul'un (2012) çalışmasında da lisansüstü eğitim düzeyinde çalışma sayısının sınırlı olduğu belirlenmiştir. Örneklem sayısının çeşitlilik gösterdiği 11-30 ile 51-100 arasında örneklemi bulunan makale sayısının en fazla olduğu belirlenmiştir. Örneklem seçiminde amaçsal örnekleme yöntemi ile uygun örnekleme yönteminin en sık kullanıldığı görülmektedir. Evrenin tamamına yönelik çalışmaların ise az olduğu belirlenmiştir. Bu veri ile uyumlu olarak Göktaş, Hasançebi ve diğ.' 'nin (2012) çalışmasında da ilk sırada uygun örnekleme tekniği, ikinci sırada ise amaca uygun örnekleme tekniğinin en çok tercih edildiği belirlenmiştir. Benzer şekilde Erdem (2011), Telli ve Yurdugül (2012) elverişli örnekleme (uygun örneklem) yönteminin en çok kullanıldığını belirlemiştir.

Nicel verilerin betimsel analizinde en çok ortalama, standart sapma, frekans ve yüzde değerleri ile veri analizi yapıldığı, kestirimsel analizde ise en çok $t$ testi ve Anova'nın kullanıldığ 1 görülmektedir. Göktaş, Hasançebi ve diğ.'nin (2012) araştırmasında kestirimsel analizde en çok $t$ testi ve Anova testi kullanılması bu veriyi desteklemektedir. Erdem (2011) de en çok t testi ve Anova testi yapıldığını belirtmiştir. Yalçın ve diğ. (2016) veri analiz yöntemlerinin kullanım sıklığında ilk sırada varyans analizinin yer aldığını belirlemiş̧ir. Yapılan çalışmalarda ilişkisel tarama çalışmalarının olması, bu oranın yüksek olmasının bir nedeni olabilir. Nitel çalışmalarda ise içerik analizi ve betimsel analizin en sık kullanıldığı, bunun yanı sıra açık kodlama, eksenel kodlama, seçici kodlama, yorumlayıcı analiz gibi yöntemlerin ise az miktarda kullanıldığı belirlenmiştir. Makalelerin genellikle Türkçe ve genişletilmiş İngilizce özetinin bulunduğu görülmektedir.

Araştırmanın sonuçlarına dayalı olarak bazı öneriler sunulmaktadır: 2018 yılından itibaren akademik özendirme ödeneği ve yükselme ölçütlerinde yapılan değişiklik sonrasında, bildiri olarak sunulan makalelerin dergilerde yayımlanma oranı ve yazar sayısı incelenebilir. Ölçütlerde yapılan değişikliğin makale yayınlama üzerine etkisi olup olmadığı araştırılabilir. Eğitim bilimleri alanında yapılan çalışmaların daha açık görülebilmesi için zaman aralığı genişletilebilir. Böylece araştırmacılara, çalışılan konular ve çalışma boşluğu olan konuları görme firsatı sunulmuş olunabilir. Eğilim çalışmalarında, meta analiz yönteminin kullanımının sınırlı kaldığı gözlemlenmiştir. $\mathrm{Bu}$ nedenle eğitim bilimleri alanındaki eğilimi belirlemek için meta analiz yöntemi kullanılarak istatistiki sonuçların ortaya çıkarılması sağlanabilir.

Yapılan çalışmada etkileşim, tasarım ve geliştirme konularında sınırlı çalışmanın olduğu belirlenmiştir. Araştırmacılar bu konulara yönelik çalışmalar yapabilir. Ayrıca incelenen makalelerde yetişkinlere ve lisansüstü öğrencilere yönelik çalışma sinırlılığı olduğu belirlenmiş̧ir. Bu nedenle yapılacak yeni çalışmalarda örneklem grubunun yetişkinler ve lisansüstü öğrencilerden oluşması sağlanabilir. 


\section{Kaynakça}

Alper, A. ve Gülbahar, Y. (2009). Trends and issues in educational technologies: A review of recent research in TOJET. The Turkish Online Journal of Educational Technology - TOJET, 8(2), 124-135.

Arık, R. S. ve Türkmen, M. (2009, Mayıs). Eğitim bilimleri alanında yayınlanan bilimsel dergilerde yer alan makalelerin incelenmesi. I. Uluslararası Türkiye Eğitim Araştırmaları Kongresinde sunulan sözlü bildiri, Çanakkale Onsekiz Mart Üniversitesi, Çanakkale.

Aztekin, S. ve Şener, Z. T. (2015). Türkiye'de matematik eğitimi alanındaki matematiksel modelleme araştırmalarının içerik analizi: Bir meta-sentez çalışması. Eğitim ve Bilim, 40(178), 139-161.

Babur, A., Kiper, A., Çukurbaşı, B., Özer, E. A., Tonbuloğlu, İ., Küçük, Ş., ... Horzum, M. B. (2016). 2009-2013 y1lları arasında uzaktan eğitim dergilerinde yayınlanan makalelerin yöntemsel açıdan incelenmesi. Sakarya University Journal of Education, 6(1), 123-140.

Bardakçı, S., Kılıçer, K. ve Özeke, V. (2017). Türkiye’de Böte bölümleri: 2015-2016 yıllarına ilişkin bir durum tespit çalışması. Eğitim Teknolojisi Kuram ve Uygulama, 7(2), 123-148.

Böke, K. (Ed.). (2009). Sosyal bilimlerde araştırma yöntemleri. İstanbul: Alfa Yayınları

Büyüköztürk, Ş., Akgün, Ö. E., Kahveci, Ö. ve Demirel, F. (2004). Güdülenme ve öğrenme stratejileri ölçeğinin Türkçe formunun geçerlilik ve güvenilirlik çalışması. Kuram ve Uygulamada Eğitim Bilimleri, 4(2), 207-239.

Büyüköztürk, Ş., Kılıç-Çakmak, E., Akgün, Ö. E., Karadeniz, Ş. ve Demirel, F. (2012). Bilimsel araştırma yöntemleri. Ankara: Pegem Akademi.

Collwill, J., and Gallagher, C. (2007). Developing a curriculum for the twenty-first century: the experiences of England and Northern Ireland. Prospects, 37, 411425.

Cooper, H., and Hedges, L. V. (2009). Research synthesis as a scientific process. H. Cooper, L. V. Hedges and J. C. Valentine (Eds.), In The handbook of research synthesis and meta-analysis (pp. 3-18). USA: Russell Sage Foundation.

Dede, C. (2010). Comparing frameworks for 21st century skills. J. Bellanca and R. Brandt (Eds.), In 21st century skills: Rethinking how students learn (pp. 51-76). USA: Solution Tree Press.

Erdem, D. (2011). Türkiye’de 2005-2006 yılları arasında yayımlanan eğitim bilimleri dergilerindeki makalelerin bazı özellikler açısından incelenmesi: Betimsel bir analiz. Eğitimde ve Psikolojide Ölçme ve Değerlendirme Dergisi, 2(1), 140147. 
Fazlığulları, O. ve Kurul, N. (2012). Türkiyedeki eğitim bilimleri doktora tezlerinin özellikleri. Mehmet Akif Ersoy Üniversitesi Eğitim Fakültesi Dergisi, 24, 4375.

Gökmen, Ö. F., Uysal, M., Yaşar, H., Kırksekiz, A., Güvendi, G. M. ve Horzum, M. B. (2017). Türkiye'de 2005-2014 yılları arasında yayınlanan uzaktan eğitim tezlerindeki yöntemsel eğilimler: Bir içerik analizi. Ĕgitim ve Bilim, 42(189), $1-25$.

Gökoğlu, S., Erdemir, T., Öztürk, M. ve Çakıroğlu, Ü. (2014). Böte sempozyumlarında sunulan çalışmalardaki eğilimler: İçerik analizi çalışması. 8. Uluslararası Bilgisayar ve Öğretim Teknolojileri Sempozyumunda sunulan sözlü bildiri, Trakya Universitesi, Edirne.

Göktaş, Y., Hasançebi, F., Varışoğlu, B., Akçay, A., Bayrak, N., Baran, M. ve Sözbilir, M. (2012). Türkiye'deki eğitim araştırmalarında eğilimler: Bir içerik analizi. Kuram ve Uygulamada Ĕgitim Bilimleri, 12(1), 443-460.

Göktaş, Y., Küçük, S., Aydemir, M., Telli, E., Arpacık, Ö., Yıldırım, G. ve Reisoğlu, İ. (2012). Türkiye'de eğitim teknolojileri araştırmalarındaki eğilimler: 20002009 dönemi makalelerinin içerik analizi. Kuram ve Uygulamada Eğitim Bilimleri Dergisi, 12(1), 177-199.

Hung, J., and Zhang, K. (2012). Examining mobile learning trends 2003-2008: A categorical meta-trend analysis using text mining techniques. Journal of Computing in Higher Education, 24(1), 1-17.

Karadağ, E. (2009). Eğitim bilimleri alanında yapılmış doktora tezlerinin tematik açıdan incelemesi. Ahi Evran Üniversitesi Kırşehir Eğitim Fakültesi Dergisi, 10(3), 75-87.

Kılıç Çakmak, E., Kukul, V., Çetin, E., Berikan, B., Kandemir, B., Pamukçu, B. S., ..., Marangoz, M. (2015). 2013 yılı eğitim teknolojileri araştırmalarının incelenmesi: AJET, BJET, C\&E, ETRD, ETS ve L\&I Dergileri. Ĕgitim Teknolojisi Kuram ve Uygulama, 5(1), 128-160.

Lee, Y., Driscoll, M., P., and Nelson, D., W. (2010). The past, present, and future of research in distance education: Results of a content analysis. American Journal of Distance Education, 18(2004), 225-241.

Lin, T. C., Lin, T. J., and Tsi, C. C. (2014). Research trends in science education from 2008 to 2012: A systematic content analysis of publications in selected journals. International Journal of Science Education, 36(8), 1346-1372.

North Central Regional Educational Laboratory and the Metiri Group (2003). Engauge 21st century skills: literacy in the digital age. Retrieved from https://pict.sdsu.edu/engauge21st.pdf 
Northup, J., Vollmer, T. R., and Serrett, K. (1993). Publication trends in 25 years of the journal of applied behavior analysis. Journal of Applied Behavior Analysis, 26(4), 527-537.

Ozan, C. ve Köse, E. (2014). Eğitim programları ve öğretim alanındaki araştırma eğilimleri. Sakarya University Journal of Education, 4(1), 116-136.

Partnership For $21^{\text {st }}$ Century Skills (2006). A state leaders action guide to 21st century skills, a new vision for education. Ohio, OH: Partnership For 21 St Century Skills.

Selçuk, Z., Palancı, M., Kandemir, M. ve Dündar, H. (2014). Eğitim ve Bilim dergisinde yayınlanan araştırmaların eğilimleri: İçerik analizi. Eğitim ve Bilim, 39(173), 430-453.

Sözbilir, M., and Kutu, H. (2008). Development and current status of science education research in Turkey [Special edition]. Essays in Education, 1-22.

Sözbilir, M., Gül, Ş., Okçu, B., Kızılaslan, A., Zoruoğlu, S. L. ve Atilla, G. (2015). Görme yetersizliği olan öğrencilere yönelik fen eğitimi araştırmalarında eğilimler. Abant İzet Baysal Üniversitesi Eğitim Fakültesi Dergisi, 15(1), 218241.

Sulzer-Azaroff, B., and Gillat, A. (1990). Trends in behavior analysis in education. Journal of Applied Behavior Analysis, 23(4), 491-495.

Şimşek, A., Özdamar, N., Uysal, Ö., Kobak, K., Berk, C., Kılıçer, T. ve Çiğdem, H. (2009). İkibinli yıllarda Türkiye'deki eğitim teknolojisi araştırmalarında gözlenen eğilimler. Kuram ve Uygulamada Eğitim Bilimleri Dergisi, 9(2), 115120.

Tavşancıl, E. ve Aslan, E. (2001). Sözel, yazılı ve diğer materyaller için içerik analizi ve uygulama örnekleri. İstanbul: (Epsilon Yayınları)

Telli, E. ve Yurdugül, H. (2012). 2009-2011 yılları arasında eğitim bilimleri araştırmalarında kullanılan örnekleme yöntemleri [Özel sayı 2]. Hacettepe Üniversitesi Ĕ̈itim Fakültesi Dergisi, 183-189.

Tsai, C. C., and Lydia Wen, M. (2005). Research and trends in science education from 1998 to 2002: A content analysis of publication in selected journals. International Journal of Science Education, 27(1), 3-14.

Turan, S., Karadağ, E., Bektaş, F. ve Yalçın, M. (2014). Türkiye’de eğitim yönetiminde bilgi üretimi: Kuram ve Uygulamada Eğitim Yönetimi Dergisi 2003-2013 yayınlarının incelenmesi. Kuram ve Uygulamada Egitim Yönetimi Dergisi, 20(1), 93-119.

Ulutaş, F. ve Ubuz, B. (2008). Matematik eğitiminde araştırmalar ve eğilimler: 2000 ile 2006 yılları arası. Ilkögretim Online, 7(3), 614-626. 
Uyar, M. Y. (2017). Eğitim programları ve öğretim alanına yönelik bir dergideki araştırmalara ilişkin içerik analizi: 2002-2015. Kastamonu Eğitim Dergisi, 25(3), 1009-1024.

Üstündağ, D. A. (2013). Türkiye'de bilgisayar ve öğretim teknolojileri eğitimi alanındaki yüksek lisans tezlerinin araştırma eğilimleri. Eğitim Teknolojisi Kuram ve Uygulama, 3(1), 55-71.

Yalçın, S., Yavuz, H. Ç. ve Dibek, M. İ. (2016). En yüksek etki faktörüne sahip eğitim dergilerindeki makalelerin içerik analizi. Ĕ̌itim ve Bilim, 40(182), 1-28.

Yıldırım, A. ve Şimşek, H. (2008). Sosyal bilimlerde nitel araştırma yöntemleri (7. baskı). Ankara: Seçkin Yayıncılık.

Zawacki-Richter, O., Baecker, E., M. and Vogt, S. (2009). Review of distance education research (2000 to 2008): Analysis of research areas, methods, and authorship patterns. International Review of Research in Open and Distance Learning, 10(6), 21-50. 


\title{
Analysis of the Articles Published in 2017 in Educational Sciences Journals Indexed in Ulakbim ${ }^{1}$
}

\begin{tabular}{cccc}
\hline ARTICLE TYPE & Received Date & Accepted Date & Published Date \\
Research Article & 05.16 .2018 & 05.02 .2019 & 05.03 .2019 \\
\hline
\end{tabular}

Betül Özaydın Özkara (D) ${ }^{2}$

Isparta University of Applied Sciences

\begin{abstract}
This study aims to examine the articles published in 14 journals indexed in the field of educational sciences in the social and human sciences database journal list Ulakbim TR in 2017. After previous forms were examined in order to determine the trends in educational sciences, new data collection forms developed by the researcher used. A total of 830 articles have been examined through this form. In the research, the name of the journal, publication period, number of authors, article subject, article method and design, data collection tools, sample level, number of samples, sampling technique, data analysis method, and the language of the article were analyzed. As a result of the analysis; most of the articles belong to two authors and the period of admission is between 1 and 6 months. It has been determined that researches on assessment and evaluation in education are the most frequently studied ones. It has been determined that quantitative method, survey design, surveys, scales and purposeful sampling technique are mostly used in researches. It has been determined that studies at the undergraduate level are mostly existed, and studies for adult and postgraduate students are limited. As a result of the research, it is thought that researchers will be able to work on educational technology, interaction, design and development which are the least studied subjects.
\end{abstract}

Keywords: Education researches, trends in educational research, 2017 educational trends, trend analysis, journal of Ulakbim.

\footnotetext{
${ }^{1}$ This study was presented at the 27th International Congress of Educational Sciences in Antalya, 18-22 April 2018.

${ }^{2}$ Corresponding Author: Inst. Dr., Distance Learning Vocational School, Departmant of Computer Use, Email: betulozaydin@isparta.edu.tr, https://orcid.org/0000-0002-2011-1352
} 


\section{Purpose and Significance}

This study was conducted in order to examine the educational sciences researches in 2017. In the study it is focused on examining the articles indexed in Educational Science research papers list in ULAKBİM database in terms of publication period, number of authors, article subject, article method and design, data collection tools, sample level, number of samples, sampling technique, data analysis method and the language of the article. Thus, it is aimed to determine the current situation of the studies conducted in 2017. Trend studies are extremely important because they are indicators of what is being done in the field and what is needed. As a result of the studies, there was no study showing what was done in the field of education in 2017. Therefore, 2017 researches were examined. Sample group was selected from TUBITAK Ulakbim database. Because these journals have to meet certain criterias. This situation requires certain quality of articles. For this reason, it is thought that the articles published in the periodicals are valuable studies, and that they are guiding the studies and applications.

\section{Method}

In the study; the articles published in 2017 by 14 journals which have been published in the field of educational sciences for the last ten years have been analyzed by content analysis method. The journals were selected from the journals reviewed by ULAKBIM. The selected journals were not considered to be the only field journals such as sports and mathematics. The names of journals with this feature are as following: Ankara University Journal of Educational Sciences, Ege Education Journal, Education and Science, Erzincan University Journal of Erzincan Education Faculty, Hacettepe University Journal Education, Elementary Education Online, Inonu University Journal of Education Faculty, Kastamonu University Journal of Kastamonu Education, Educational Administration: Theory And Practice, Mersin University Journal of Education Faculty, Ondokuz Mayis University Journal of Education Faculty, Uludag University Journal of Education Faculty, Yuzuncu Y1l University Journal of Education Faculty and Gazi University Journal of Gazi Education Faculty. A total of 830 articles were analyzed by document analysis method. A data collection form was created to collect the data. Forms used in previous studies had been examined before the form was created. The new form was created by using the previous forms. This form consist of article name, the name of the journal on which the article is printed the status of working of the article (report or thesis), the date of submitting of the article, the date of acceptance of the article, number of authors, article of topic, article method, data collection tools, sample level, sample number, sampling technique, data analysis method and language of the article. Fourteen papers published in different journals have been analyzed by another investigator to ensure reliability in the study. Percent of agreement was found to be $87 \%$. In addition, the researcher re-analyzed 30 articles published in different journals with a two-week interval. Percent of agreement was found to be $94 \%$. Thus, it was determined that the inter-scorer and the intra-scorer reliability are high. 
Descriptive analysis and content analysis methods were used in data analysis. In the process of determining the article topics, all the articles were examined and the subjects were taken out. These issues were grouped and the articles were re-examined and the accuracy of the subjects were checked. As a result of this grouping, 6 subject areas were formed. Article topics are determined as following: Assessment and evaluation in education, psychological services in education learning-teachingevaluation approaches, methods and techniques, education management, educational technology and other topics. Some of these subject areas explained below.

Assessment and evaluation in education. Article topics are determined as following: evaluation of individuals by others, student and teacher competence, education process, teaching system, supervision system, course, unit, curriculum, education model, evaluation of the examination system, books, thesis, articles, exam questions, homework and form of materials such as the evaluation is concerned.

Psychological services in education. Perception in individuals, opinions of individuals, awareness of individuals, self-efficacy beliefs, readiness, self-evaluation of individuals, studies of metaphors about others, anxiety, commitment, addiction, compassion, hopelessness, burnout, mobbing, stress, violence, conflict, aggression and so on. The subjects related to the psychology of the individuals are the articles.

Learning-teaching-evaluation approaches, methods and techniques. The methods, approaches and techniques used in the learning teaching process include the articles in which the studies are included.

Education management. Job satisfaction, job quality of life, organizational justice, organizational culture, educational environment, problems in the educational environment and interaction includes activities such as.

Educational technology. Computer-aided education, learning / teaching tools, educational software, educational website, augmented reality, technology leadership, information technologies, social networks, cyber bullying and cyber security studies, mathematics literacy, financial literacy, media literacy, design and development topics such as.

Other topics. Such as working subjects; environment, environmental pollution, spouse selection, entrepreneurship, nutrition, identity style, autism.

The research topics, data collection tools, such as the other topics examined outside the subject area by using the different books were created as a result of the article review.

\section{Results}

To determine the current status of articles in the field of educational sciences in 2017, a total of 830 articles in 14 journals which have been published in Ulakbim TR index of social sciences and humanities database in the field of educational sciences and have been published during the last decade have been examined. As a result of 
this examination, some of the published articles belong to a master's or doctoral dissertation or they were previously presented as a report. In the journals analyzed, it was determined that the publication period was mostly between 1-6 months. It was determined that the date of submission and dates of acceptance differ according to the journals. The amount of articles with two authors is more than half of all articles. The number of authors ranges from 1 to 8 . The articles of topic was 6 grouped. Assessment and evaluation in education have been identified as the most frequent studies. Research methodology was changed as quantitative, qualitative, mixed method, field compilation, and tool development. In the research methods used in the articles, it was determined that the most quantitative method followed by the qualitative method. Tools such as semi-structured interviews, observations, documents, other instruments (form, self-assessment report, performance test, etc.), an existing scale / questionnaire, scale / questionnaire developed in the research achievement tests were used as data collection tools. It was determined that questionnaires and scales were more common as data collection tools. It was determined that the most of the studies were conducted at the undergraduate level and the studies with the teachers took place. Studies with graduate students and adults are limited. Appropriate sampling and purposeful sampling methods were more used as the sampling method. Descriptive and inferential statistical methods were used in quantitative studies in data analysis. In the analysis of qualitative studies, descriptive analysis and content analysis were used.

\section{Discussion and Conclusions}

As a result of the research, it was determined that assessment and evaluation in education and psychological services in education were studied more in these subject topic. The number of authors has been determined to concentrate at 1 and 2 . There are studies supporting this finding (Alper and Gülbahar, 2009; Ozan and Köse, 2014; Turan, Karadağ, Bektaş and Yalçın, 2014) Experimental investigations and screening models appear to be used more frequently in quantitative research. It was seen that the varieties are used more frequently in the quantitative method. In some studies (Arık and Türkmen, 2009; Göktaş, Hasançebi et all., 2012; Ozan and Köse, 2014; Selçuk, Palanc1, Kandemir and Dündar, 2014; Şimşek et all., 2009) the use of qualitative method in the first order and the use of qualitative research method in the second order support this data. The most widely used data collection tools were previously developed questionnaires and scales. Similarly, in some studies (Erdem 2011; Göktaş, Küçük et all., 2012; Ozan and Köse, 2014) the most preferred data collection tool was the survey. It was determined that the most of the studies were conducted at the undergraduate level and the studies with the teachers took place. Similarly, in some studies (Göktaş, Hasançebi et all., 2012; Ozan and Köse, 2014) the same sample levels were found to be the most preferred. In the study of Yalçın, Yavuz and Dibek (2016), it was determined that there was a study about primary and high school students. In the study of Fazlıogulları and Kurul (2012), it was determined that the number of studies at the graduate level was limited. It is seen that aim sampling method and appropriate sampling method are used most frequently in the sample selection. It is seen that there are studies supporting this finding (Erdem, 2011; Göktaş, Hasançebi 
et all., 2012; Telli and Yurdugül, 2012). Some suggestions are presented based on the results of the study: In the study, limited study on interaction, design and development has been found. Researchers can work on these issues. In addition, it has been determined that there is a limitation on working towards adults and graduate students. Therefore, it can be ensured that the sample group consisting of adults and graduate students. 